\title{
Isoform profile of NOS enzyme in structure of rats' solitary-vagal complex in arterial hypertension of various origin
}

\author{
M. V. Danukalo*B,C,D, O. V. Hancheva ${ }^{A, E, F}$ \\ Zaporizhzhia State Medical University, Ukraine
}

A - research concept and design; B - collection and/or assembly of data; C - data analysis and interpretation; D - writing the article; $\mathrm{E}$ - critical revision of the article; $\mathrm{F}$ - final approval of the article

The aim of this study was to characterize the nitric oxide isoforms profile in rats' nucleus tractus solitarii (NTS) and dorsal motor nucleus $(\mathrm{DMN})$ of vagus nerve in arterial hypertension $(\mathrm{AH})$ of various origin (essential $(\mathrm{EAH})$ - rats of SHR line, and endocrine-salt $\mathrm{AH}$ ).

Materials and methods. The study was performed on 30 aged male rats. Among them, 20 Wistar rats were divided into two groups control (10 rats) and 10 rats with simulated endocrine-salt AH (ESAH) and 10 SHR rats. An immunohistochemical method was used to study the of nitric oxide synthase isoforms expression features in DMN and NTS. The following parameters were determined: the content of immunoreactive material (IRM) for the studied peptides $\left(U_{\text {if }}\right)$, the relative area of the IRM $(\%)$ and the IRM concentration in $1 \mu \mathrm{m}^{2}\left(\mathrm{U}_{\mathrm{if}} / \mu \mathrm{m}^{2}\right)$.

Results. It was found that in rats with both models of $\mathrm{AH}$, the expression indices of all three nitric oxide synthase (NOS) isoforms in the studied structures increased. In our opinion, this is due to the activation of the studied structures in AH conditions. This must be considered as an important element of high blood pressure compensating. It is achieved through the implementation by a complex of mechanisms like reducing of the sympathetic tone and increasing of the parasympathetic tone by activating a system of secondary messengers; improving neurotrophy due to the high activity of constitutive NOS isoforms; iNOS-mediated NO overproduction, as a factor in compensating for its bioavailability in conditions of local ischemia in $\mathrm{AH}$.

Conclusions. Regardless of the AH etiopathogenesis in both experimental groups, the expression of all three NOS isoforms increases in the DMN and NTS structures. In rats with EAH in the DMN and NTS structures, the expression indices of NOS isoforms have their own characteristics. So in the first structure, the largest changes in the indices of the immunoreactive material content and concentration are observed for eNOS, and the relative area for iNOS. At the same time, in the NTS structure, the largest changes in the content indices are observed for iNOS, and the concentration and relative area for eNOS. In rats with ESAH in the DMN structure, the highest changes in the indices of IRM content and concentration are observed for the endothelial isoform of NOS, and the relative area - for inducible. In the NTS structure, the IRM content changed the most for nNOS, and the concentration and relative area for iNOS.

Ізоформний профіль ферменту NOS у структурі солітарно-вагального комплексу щурів при артеріальній гіпертензії різного ґенезу

\section{М. В. Данукало, О. В. Ганчева}

Мета роботи - дати характеристику ізоформного профрілю синтази оксиду азоту (NOS) у структурах ядра солітарного тракту (ЯСТ) і дорсального моторного ядра (ДМЯ) щурів при артеріальній гіпертензії (АГ) різного ґенезу (есенціальній - ЕАГ) - щури лінії SHR, та ендокринно-сольовій АГ.

Матеріали та методи. Дослідження здійснили на статевозрілих 30 щурах-самцях, серед них - 20 тварин лінії Wistar, яких поділили на дві групи: контроль (10 щурів) і 10 щурів зі змодельованою ендокринно-сольовою АГ (ЕСАГ), 10 щурів лінії SHR - із генетично детермінованою АГ. Для дослідження особливостей експресії ізоформ NOS у ДМЯ та ЯСТ використовували імуногістохімічний метод. Визначали параметри: вміст імунореактивного матеріалу (IPM) до досліджуваних пептидів (Од і концентрацію досліджуваної речовини в 1 мкм² $\left(\right.$ Од $_{\text {iф }}$ мкм²$\left.^{2}\right)$.

Результати. Протягом дослідження встановили, що в щурів обох моделей з АГ показники експресії всіх трьох ізоформ NOS y досліджуваних структурах збільшуються. На нашу думку, це пов'язано з активацією структур, що дослідили, під час АГ. Це необхідно розглядати як важливий елемент компенсації підвищеного артеріального тиску, який здійснюється внаслідок реалізації комплексу механізмів: зниження тонусу симпатичної нервової системи та підвищення тонусу парасимпатичної нервової системи шляхом активації нейрорегуляторних програм корекції судинного тонусу через систему вторинних месенджерів; поліпшення нейротрофріки внаслідок високої активності конститутивних ізоформ NOS; iNOS-опосередкованої гіперпродукції NO як фрактора компенсації його біодоступності в умовах локальної ішемії під час АГ.

UDC 616.12-008.331.1:616.831.9:612.822.015.11-092.9:599.323.4

DOI: $10.14739 / 2409-2932.2020 .1 .198141$

Current issues in pharmacy and medicine: science and practice 2020; 13 (1), 78-83

Key words: nitric oxide synthase, nucleus of the solitary tract, dorsal motor nucleus, brain stem, hypertension, rats.

*E-mail: danukalo@zsmu.pp.ua

Received: 04.11.2019 // Revised: 09.12.2019 // Accepted: 12.12.2019 
Висновки. Незалежно від етіопатогенезу АГ в обох експериментальних групах у структурах ДМЯ та ЯСТ збільшується експресія всіх трьох ізоформ NOS. У щурів з ЕАГ у структурі ДМЯ та ЯСТ показники експресії ізоформ NOS мають особливості. Так, у першій структурі найбільші зміни показників умісту та концентрації IPM спостерігали для eNOS, а відносної площі - для iNOS. У структурі ЯСT найбільші зміни показників вмісту визначили для iNOS, а концентрації та відносної площі - для eNOS. У щурів 3 ЕСАГ у структурі ДМЯ найбільші зміни вмісту та концентрації визначили для ендотеліальної ізоформи NOS, а відносної площі для індуцибельної. У структурі ЯСТ уміст IPM найбільше змінився для nNOS, а концентрація та площа - для iNOS.

Ключові слова: синтаза оксиду азоту, ядро солітарного тракту, дорсальне моторне ядро, стовбур мозку, артеріальна гіпертензія, щури. Актуальні питання фрармацевтичної і медичної науки та практики. 2020. Т. 13, № 1(32). С. 78-83

\section{Изоформный профиль фермента NOS в структуре солитарно-вагального комплекса крыс при артериальной гипертензии различного генеза}

\section{М. В. Данукало, О. В. Ганчева}

Цель работы - дать характеристику изоформного профиля синтазы оксида азота (NOS) в структурах ядра солитарного тракта (ЯСТ) и дорсального моторного ядра (ДМЯ) крыс при артериальной гипертензии (АГ) различного генеза (эссенциальной - ЭАГ) крысы линии SHR, и эндокринно-солевой АГ.

Материалы и методы. Исследование проведено на половозрелых 30 крысах-самцах, среди которых 20 животных линии Wistar, поделенные на две группы: контроль (10 крыс) и 10 крыс с смоделированной эндокринно-солевой АГ (ЭСАГ), 10 крыс линии SHR - с генетически детерминированной АГ. Для исследования особенностей экспрессии изоформ NOS в ДМЯ и ЯСT использовали иммуногистохимический метод. Определяли параметры: содержание иммунореактивного материала (ИРМ) к исследуемым

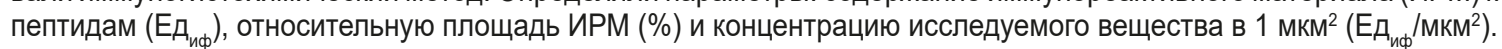

Результаты. В ходе исследования установили, что у крыс обеих моделей с АГ показатели экспрессии всех трех изоформ NOS в изучаемых структурах увеличиваются. По нашему мнению, это связано с активацией этих структур при АГ. Это необходимо рассматривать как важный элемент компенсации повышенного АД, который осуществляется за счет реализации комплекса механизмов: снижения тонуса симпатической нервной системы и повышения тонуса парасимпатической нервной системы путем активации нейрорегуляторных программ коррекции сосудистого тонуса через систему вторичных мессенджеров, улучшения нейротрофики за счет высокой активности конститутивных изоформ NOS; iNOS-опосредованной гиперпродукции NO как фактор компенсации его биодоступности в условиях локальной ишемии при АГ.

Выводы. Вне зависимости от этиопатогенеза АГ в обеих экспериментальных группах в структурах ДМЯ и ЯСТ увеличивается экспрессия всех трех изоформ NOS. У крыс с ЭАГ в структуре ДМЯ и ЯСТ показатели экспрессии изоформ NOS имеют особенности. Так, в первой структуре наибольшие изменения показателей содержания и концентрации ИPM отмечены для eNOS, a относительной площади - для iNOS. B структуре ЯCT наибольшие изменения показателей содержания установлены для iNOS, а концентрации и относительной площади - для eNOS. У крыс с ЭСАГ в структуре ДМЯ наибольшие изменения содержания и концентрации отмечены для эндотелиальной изоформы NOS, а относительной площади - для индуцибельной. В структуре ЯСТ содержание ИPM наиболее изменилось для nNOS, а концентрация и площадь - для iNOS.

Ключевые слова: синтаза оксида азота, ядро солитарного тракта, дорсальное моторное ядро, ствол мозга, артериальная гипертензия, крысы.

Актуальные вопросы фрармацевтической и медицинской науки и практики. 2020. Т. 13, № 1(32). С. 78-83

Arterial hypertension (AH) is characterized by a variety of etiological factors and multicomponent links of pathogenesis. Most researchers agree that its development is based on disturbances in the functioning of blood pressure (BP) regulation systems [1]. The most important BP coordinators are brainstem structures, as primary analyzers of the afferent information about the condition of vascular tone. Moreover, they provide an efferent response that supports BP homeostasis in the case of its change. These structures, first of all, are the nucleus of the solitary tract (NTS) and the dorsal motor nucleus (DMN) n. vagus. They regulate BP by activating a number of reflexes; the most important of them is the baroreflex. In this context, NTS is considered as an important afferent link, while DMN is an efferent component [2]. So, it is logical to assume that a change in the NTS and DMN functional state will be displayed on the BP regulation.

It has been established today that gaseous transmitters act as important regulators of the neurons' functional activity. The most studied of them is nitrogen monoxide (NO). A number of researchers have already demonstrated disturbances in the NO system in the BP regulatory centers of the brain in $\mathrm{AH}$. It was found that they are associated with both quantitative and qualitative features of NO systems ' components (presence of substrate, isoform profile of the enzyme, bioavailability of NO) $[3,4]$. Unfortunately, the process of directly determining NO amount in tissues is expensive and time-consuming. Therefore, indirectly, the NO amount in tissues can be measured by the level of nitric oxide synthase (NOS) isoforms expression. It is proved that each isoform is involved in the implementation of a certain complex of $\mathrm{NO}$ effects. The nitrogen monoxide produced by the endothelial isoform of NOS leads to vasodilation, inhibition of aggregation and adhesion of platelets and leukocytes, activation of endothelial progenitor cells, stimulation of angiogenesis; neuronal isoform - regulates synaptic transmission, acts as a neuroprotector and neurotransmitter; inducible isoform - to the production of a large number of free radicals and their mediated cytotoxicity. 
In this regard, it can be argued that in order to obtain a holistic picture of NO-dependent processes, it is important to study the entire NOS isoform profile in the structures under study. All three NOS isoforms were found in NTS and DMN [6], but data about the features of their expression in brainstem regulatory centers in $\mathrm{AH}$ are insufficient.

\section{Aim}

Therefore, the aim of this work was to characterize the NOS isoform profile in rats ' NTS and DMN structures in arterial hypertension of various origins.

\section{Materials and methods}

The study was performed on 20 mature male Wistar rats and 10 male rats of the SHR line (generally accepted model of essential AH (EAH) in humans [7], mean weight $-249.9 \pm 12.0 \mathrm{~g})$. 10 male Wistar rats were in a control group (mean weight $187.2 \pm 6.3 \mathrm{~g}$ ), in other 10 we modeled endocrine-saline hypertension (ESAH), which is analogue of endocine-assosiated $\mathrm{AH}$ in humans (mean weight $-263.7 \pm 7.2 \mathrm{~g}$ ).

The rats used in the study were obtained from the nursery "Biomodelservice" Kyiv. The experimental part of the study was carried out in accordance with the "General Ethical Principles of Animal Experiments" (Ukraine, 2001), which are adjusted with the statement of Europe Parliment Council 2010/63EU and Council from 22 of September 2010 on the protection of animals used for scientific purposes (Council Directive 2010/63EU of the European Parliament and of the Council of 22 September 2010 on the protection of animals used for scientific purposes).

ESAH was modeled by intraperitoneal injection of medication prednisolone (30 days, 2 times a day, $7.00 \mathrm{am}-2 \mathrm{mg} / \mathrm{kg}, 8.00 \mathrm{pm}-$ $4 \mathrm{mg} / \mathrm{kg}$, with forced intake of $5 \mathrm{ml}$ of a $2.3 \%$ solution of $\mathrm{NaCl}$ ) [8]. To measure BP, the animal is housed in special immobilization boxes located on a platform, which is heated and constantly maintains a constant temperature of $37-39^{\circ} \mathrm{C}$. The peculiarity of the boxes is that they are light-tight. This minimizes the additional irritation and shaking of the animal. The blood pressure measurement procedure is carried out in absolute silence. The average time to register BP is 3-7 minutes. During this time it is possible to take $3-5$ preliminary measurements and $3-5$ control measurements. The unit automatically calculates systolic, diastolic pressures and heart rates [9]. BP indices in the control were 110/75 $\pm 5 \mathrm{mmHg}$; in EAH - 165/100 $\pm 5 \mathrm{mmHg}$, ESAH was $155 / 90 \pm 5 \mathrm{mmHg}$.

The object of the study was the brain stem of experimental animals. Decapitation was performed under thiopental anesthesia (40 mg/kg intraperitoneally). Topographic identification of the NTS and DMN structures was carried out with the help of stereotaxic rat brain atlas [10].

Histochemical processing for immunohistochemical examination of NTS and DMN structures was conducted in a next way. After decapitation immediately, within 2-3 minutes, the brain was removed and it was placed for 20 hours in a Buen solution which was prepared ex tempore from a saturated aqueous solution of picric acid (1.2\%), concentrated formal- dehyde (35-40\%) and glacial acetic acid in a ratio of $15: 5: 1$, respectively. After 20 hours of fixation, the brain was subjected to 2 hours of washing under cold running water to wash out picric acid. The procedure was followed by dehydration of the organ in ascending concentrations of ethanol, namely: $50 \%, 60 \%, 70 \%, 80 \%, 90 \%, 96 \%, 100 \%-1,100 \%-2$, then in solutions: ethanol $100 \%+$ chloroform $2: 1$, ethanol $100 \%+$ chloroform $1: 1$, ethanol $100 \%+$ chloroform $1: 2$, chloroform, chloroform + paraplast (MkCormick, USA) $1: 3$ $\left(\mathrm{T}=+37^{\circ} \mathrm{C}\right)$, placed in liquid for 1 hour paraplast (MkCormick, USA) $\left(\mathrm{T}=+56^{\circ} \mathrm{C}\right)$ and then placed in paraplast blocks.

The expression of NOS isoforms was studied by an immunohistochemical method. All antibodies used were diluted $1: 200$ (Santa Cruz Biotechnology, USA). Serial $7 \mu \mathrm{m}$ brain stem sections after above described histochemical processing were incubated with rabbit $\mathrm{IgG}$ to nNOS, with rabbit $\mathrm{IgG}$ to eNOS, with mouse IgG to iNOS conjugated to FITC. Then, secondary murine anti-rabbit $\mathrm{IgG}$ antibodies conjugated with FITC were applied to glasses coated with primary IgG to nNOS and eNOS (after 3 times washing in phosphate buffer solution) and placed in a mixture of glycerol / phosphate buffer $(9: 1)$.

Specificity control was carried out by applying blocking peptides corresponding to primary antibodies. Further stages of immunohistochemical staining were carried out similarly to the method described above [11].

Immunofluorescence studies of brainstem sections prepared by the above-described method were performed in the ultraviolet spectrum using a $38 \mathrm{HE}$ filter (Zeiss, Germany) on AxioImager-M2 microscope (Zeiss, Germany) through a sensitive camera AxioCam-5HRm (Zeiss, Germany). Images obtained in this way were processed interactively, with a determination of the zone corresponding to an NTS and DMN with statistically significant fluorescence. In the selected zone of interest, the content $\left(\mathrm{U}_{\mathrm{if}}\right)$, relative area of the immunoreactive material (IRM) (\%) and the concentration of the studied NOS isoform in $1 \mu \mathrm{m}^{2}\left(\mathrm{Uif} / \mu \mathrm{m}^{2}\right)$ were determined. The microphotographs of the NTS and DMN were processed using the image analysis program - Image $J$ [12]. To determine the reliability of the differences in the samples studied, the Student's test and, if necessary, the Whitney-Mann criterion were used, respectively. Differences were considered significant for $\mathrm{P}<0.05$ [13].

\section{Results}

A comparative analysis of NOS isoforms expression indices in the DMN structure showed significant differences between the control and experimental groups. Thus, nNOS expression values showed that in EAH rats, the content, concentration and relative area of the IRM were higher than the control values by $34.4 \%, 30.5 \%$, and $18.0 \%$, respectively. At the same time, in ESAH rats only the content and concentration of IRM to nNOS were significantly higher by $70.9 \%$ and $13.0 \%$, respectively (Table 1).

A comparison of nNOS expression values in animals of experimental groups with $\mathrm{AH}$ showed their different directions. Thus, in ESAH rats, compared to EAH rats, a significantly higher IRM content was noted by $27.1 \%$, but significantly 
Isoform profile of NOS enzyme in structure of rats' solitary-vagal complex in arterial...

Table 1. Parameters of NOS isoforms expression in the DMN structure of experimental animals $(M \pm m)$

\begin{tabular}{|c|c|c|c|}
\hline Experimental groups & Content of IRM (Unit if $_{\text {) }}$ & Concentration of IRM $\left(U_{i f} / m^{2}\right)$ & Relative area of the IRM (\%) \\
\hline \multicolumn{4}{|l|}{ nNOS } \\
\hline Control & $244.24 \pm 10.65$ & $59.88 \pm 1.38$ & $45.74 \pm 1.30$ \\
\hline EAH & $328.41 \pm 17.36^{*}$ & $78.19 \pm 2.34^{*}$ & $54.00 \pm 0.63^{*}$ \\
\hline ESAH & $417.56 \pm 14.03^{\star \#}$ & $67.67 \pm 1.06^{\text {« }}$ & $44.94 \pm 0.56^{\#}$ \\
\hline \multicolumn{4}{|l|}{ iNOS } \\
\hline Control & $266.43 \pm 11.78$ & $57.24 \pm 1.21$ & $44.64 \pm 1.11$ \\
\hline EAH & $375.57 \pm 12.69^{*}$ & $73.89 \pm 1.08^{*}$ & $54.20 \pm 0.75^{*}$ \\
\hline ESAH & $447.28 \pm 13.86^{\star \#}$ & $64.38 \pm 0.62^{\star *}$ & $48.42 \pm 0.56^{\text {*\# }}$ \\
\hline \multicolumn{4}{|l|}{ eNOS } \\
\hline Control & $269.38 \pm 10.92$ & $57.45 \pm 1.33$ & $45.27 \pm 1.02$ \\
\hline $\mathrm{EAH}$ & $517.99 \pm 14.45^{*}$ & $75.66 \pm 0.96^{*}$ & $54.99 \pm 0.61^{*}$ \\
\hline ESAH & $470.36 \pm 14.09^{* \#}$ & $67.09 \pm 0.99^{\star * \#}$ & $44.43 \pm 0.73^{\#}$ \\
\hline
\end{tabular}

*: significant difference in parameters $(P<0.05)$ of rats of the experimental groups in relation to the control; \#: significant difference in parameters $(P<0.05)$ of rats between groups with experimental arterial hypertension.

Table 2. Parameters of NOS isoforms expression in the NTS structure of experimental animals $(\mathrm{M} \pm \mathrm{m})$

\begin{tabular}{|c|c|c|c|}
\hline Experimental groups & Content of IRM (Unit & Concentration of IRM $\left(\mathrm{U}_{\mathrm{if}} / \mathrm{m}^{2}\right)$ & Relative area of the IRM (\%) \\
\hline \multicolumn{4}{|l|}{ nNOS } \\
\hline Control & $282.30 \pm 10.47$ & $64.17 \pm 1.31$ & $44.52 \pm 1.08$ \\
\hline $\mathrm{EAH}$ & $399.76 \pm 13.82^{*}$ & $77.55 \pm 1.80^{*}$ & $53.47 \pm 0.56^{*}$ \\
\hline ESAH & $480.31 \pm 13.74^{\star \#}$ & $67.60 \pm 0.60^{* \#}$ & $45.52 \pm 0.47^{\#}$ \\
\hline \multicolumn{4}{|l|}{ iNOS } \\
\hline Control & $308.95 \pm 12.84$ & $58.11 \pm 1.23$ & $45.03 \pm 1.10$ \\
\hline $\mathrm{EAH}$ & $473.81 \pm 11.25^{*}$ & $73.60 \pm 0.90^{*}$ & $52.48 \pm 0.58^{\star}$ \\
\hline $\mathrm{ESAH}$ & $467.31 \pm 12.06^{*}$ & $63.97 \pm 0.75^{\star \#}$ & $50.25 \pm 0.67^{\text {*\# }}$ \\
\hline \multicolumn{4}{|l|}{ eNOS } \\
\hline Control & $398.32 \pm 10.75$ & $61.82 \pm 1.04$ & $42.21 \pm 1.07$ \\
\hline $\mathrm{EAH}$ & $486.00 \pm 12.26^{*}$ & $79.13 \pm 0.95^{\star}$ & $51.93 \pm 0.60^{*}$ \\
\hline ESAH & $537.98 \pm 14.27^{*}$ & $64.86 \pm 0.85^{\star \#}$ & $45.62 \pm 0.61^{\text {\#\# }}$ \\
\hline
\end{tabular}

*: significant difference in parameters $(P<0.05)$ of rats of the experimental groups in relation to the control; \#: significant difference in parameters $(P<0.05)$ of rats between groups with experimental arterial hypertension.

lower concentration by $13.45 \%$ and the relative area of the IRM by $16.7 \%$, respectively (Table 1 ).

In $\mathrm{AH}$ groups, the indices of iNOS expression significantly increased in comparison with normotensive control. So, in EAH animals, the IRM content to iNOS was higher by $40.9 \%$, the IRM concentration - by $29.0 \%$, and the relative area - by $21.4 \%$. The iNOS expression indices in ESAH group in comparison to the control were significantly higher: content by $67.8 \%$; concentration $-12.4 \%$, relative area-by $8.9 \%$. A comparative analysis of data between $\mathrm{AH}$ groups showed a similar change with nNOS values. At the same time, in the ESAH group in comparison with EAH, with significant predominance of the IRM content to iNOS by $19 \%$, lower concentrations were observed by $12.8 \%$ and the relative area of the IRM by $10.6 \%$ (Table 1 ).
The eNOS expression data in DMN structure of experimental animals showed that in EAH rats all studied parameters were significantly higher than the values of normotensive control. The content of IRM to eNOS was higher by $92.2 \%$, the concentration of IRM -by $31.7 \%$, the relative area of the IRM - by $11.9 \%$. In ESAH group, the content of IRM to eNOS in the DMN structure of was by $74.6 \%$ higher, the concentration - by $16.7 \%$ higher, and the relative area did not significantly differ from the control values. When comparing the parameters of the experimental groups with $\mathrm{AH}$, it was found that absolutely all studied parameters of enzyme isoforms expression in animals with ESAH were significantly lower than the values of rats with EAH. The IRM content was 
$9.2 \%$ lower, the concentration $-11.3 \%$, and the relative area $-19.2 \%$ (Table 1$)$.

The next stage was the study of the above-described parameters of the NOS isoforms expression in NTS structure. They are shown in Table 2.

Studied indices of nNOS expression in the EAH group of rats were significantly higher than the values of normotensive animals. Thus, the IRM content to nNOS exceeded by $41.6 \%$, the concentration - by $20.9 \%$, and the relative area of the IRM to isoform - by $20.1 \%$. At the same time, in ESAH rats, only the IRM content and concentration to nNOS were significantly higher by $70.1 \%$ and $5.3 \%$, respectively. Differences between $\mathrm{AH}$ groups in nNOS expression indices in NTS structure were found to be interesting. ESAH animals in comparison with EAH showed significantly lower values of the IRM concentration and relative area to the studied enzyme by $12.8 \%$ and $15.1 \%$, respectively. Moreover, the nNOS content in the NTS structure of ESAH rats was significantly higher by $20.1 \%$ compared with EAH rats (Table 2).

In the NTS structure in both experimental AH groups in relation to the control group, the iNOS expression indices were significantly higher. So, in EAH rats, the content, concentration and relative area of the IRM to iNOS were higher by $53.3 \%$, $26.6 \%$, and $16.5 \%$, respectively. In ESAH animals, the prevalence of expression values relative to the control was $51.2 \%$, $10.1 \%, 11.6 \%$, respectively. Comparison between AH groups showed, that in ESAH animals in relation to the EAH group, only the IRM concentration and area to iNOS were significantly lower by $13.1 \%$ and $4.2 \%$, respectively (Table 2 ).

Indices of eNOS expression in EAH rats showed significantly higher digital values compared to the control. So, the content of eNOS in the NTS structure was $22 \%$ higher, the concentration $-28 \%$, the relative area $-23 \%$. Similar parameters in ESAH rats showed differences from the control values by $35 \%$ higher content, concentration $-4.9 \%$, and relative area $-8 \%$. Intergroup differences were also found during the analysis of eNOS expression data. It was found that the concentration and relative area of the IRM to eNOS in ESAH animals compared with EAH animals was significantly lower by $18 \%$ and $12 \%$, respectively, and the content was $10.7 \%$ higher (Table 2).

\section{Discussion}

The data obtained in the study indicate that in the DMN and NTS structures in AH an increase in the expression of all 3 NOS isoforms is observed. And it has no dependence on the etiopathogenetic mechanisms of $\mathrm{AH}$ occurrence. At the same time, the increased content of NOS isoforms reflects the state of the nitrogen monoxide system as a whole and indicates its high activity in $\mathrm{AH}$. The revealed high values of their indices in DMN and NTS in animals of both experimental AH models most likely indirectly indicate an increase in functional activity. It can be realized due to increased vascularization and neurotransmission. The result of the increased activity of DMN neurons will be an increase in the vagal effects. At the same time an increase of NTS functional activity leads to the implementation of a baroreflex response to a systemic
BP increase, which contributes to its decrease. Moreover, the increased expression of three NOS isoforms, which will result in a significant $\mathrm{NO}$ content increase, becomes one of the key factors in progressive neurodegeneration in $\mathrm{AH}$ [14].

The NO-dependent mechanism of a change in the functional activity of neurons has been described quite well in the studies. It was shown in them that under NO influence in sympathetic neurons, cGMP inhibits cAMP, increasing its hydrolysis by PDE2A phosphodiesterase. This causes a decrease in cAMP-dependent phosphorylation of calcium channels and inhibition of neurotransmission. Whereas in parasympathetic neurons, NO, indirectly through cGMP, inhibits PDE3 phosphodiesterase, as a result, cAMP hydrolysis, on the contrary, decreases. This leads to increased cAMP-dependent phosphorylation of calcium channels and promotes the release of acetylcholine $[5,15]$. The result of increased DMN neurons activity will be an increase in the vagal effect, while NTS is the implementation of a baroreflex response to a systemic BP increase, which contributes to its decrease.

Evidence of the dependence of the NO effect from structure functional activity was obtained by Ogawa et al. It was shown that in NTS NO potentiates the release of glutamate by neurons [16], thus enhancing the baroreflex response to increased BP.

No less interesting was the research of the relationship between the nNOS expression and the affinity of the imidazoline NTS receptors. Thus, it was experimentally found that inhibition of nNOS violates the central hypotensive effect of clonidine and relinidin. As a result of a decrease in the local formation of NO, the affinity of the imidazoline receptors decreases, resulting in an increase in the activity of the sympathetic nervous system and increased secretion of catecholamines [17]. While an increase in the NO content as a result of high expression of the enzymes that form it, it is necessary to consider it as one of the hypotensive mechanisms of the central regulation of blood pressure.

Another possible reason for the increased activity of the NO system may be the low bioavailability of nitrogen oxide, and together with its high values, it become one of the components of progressive neurodegeneration in $\mathrm{AH}$. So, in a number of studies, it was shown that in $\mathrm{AH}$, the bioavailability of NO decreases due to increased generation of superoxide radicals. Last ones' formation can be enhanced by an increased amount of angiotensin II, which contributes to the activation of NADPH-oxidase, and excessive iNOS activity with the formation of peroxynitrite $[18,19]$. This may explain the increased expression of iNOS established in the work in the DMN and NTS structures. iNOS, as a calciumindependent isoform of the NOS in ischemic condition, becomes the main source of NO for the full functioning of neurons in $\mathrm{AH}$, but due to its low bioavailability and large amount, the implementation of its physiological effects is impaired, and its metabolites become damage factors.

Summarizing, we can say that the high activity of the NO system in DMN and NTS in AH should be considered as an important element of compensating for increased BP, which is realized through a set of mechanisms: reducing of the sympathetic tone and increasing parasympathetic tone 
due to activating neuroregulatory programs for correcting vascular tone through a system of secondary messengers; improvement of neurotrophy due to the high activity of constitutive NOS isoforms; iNOS-mediated overproduction of $\mathrm{NO}$, as a factor in compensating for its bioavailability in conditions of local ischemia in $\mathrm{AH}$, but also the pathogenetic factor of progressive neurodegeneration in hypertension.

\section{Conclusions}

Based on the study, the following conclusions can be made:

1. Regardless of the etiopathogenesis of arterial hypertension in both experimental groups the expression of all three NOS isoforms increases in the DMN and NTS structures

2. In EAH rats in the DMN and NTS structure, the expression indices of NOS isoforms have their own characteristics. So in the first structure, the largest changes in the indices of the IRM content and concentration are observed for eNOS, and the relative area for iNOS. At the same time, in the NTS structure, the largest changes in the IRM content are observed for iNOS, and the concentration and relative area for eNOS.

3. In ESAH rats in the DMN structure, the highest changes in the indices of IRM content and concentration are observed for the endothelial isoform of NOS, and the relative area for inducible. In the NTS structure, the IRM content changed the most for nNOS, and the concentration and relative area for iNOS.

\section{Funding}

This study is a part of Zaporizhzhia State Medical University research work: "The role of hypothalamic and brain stem peptidergic structures in the pathogenesis of arterial hypertension" (State registration number 0117U002579).

Conflicts of interest: authors have no conflict of interest to declare. Конфлікт інтересів: відсутній.

Information about authors:

Danukalo M. V., Assistant of the Department of Pathological Physiology, Zaporizhzhia State Medical University, Ukraine.

Hancheva O. V., MD, PhD, DSc, Professor, Head of the Department of Pathological Physiology, Zaporizhzhia State Medical University, Ukraine.

Відомості про авторів:

Данукало М. В., асистент каф. патологічної фрізіології, Запорізький державний медичний університет, Україна.

Ганчева О. В., д-р мед. наук, професор, зав. каф. патологічної фізіології, Запорізький державний медичний університет, Україна.

Сведения об авторах:

Данукало М. В., ассистент каф. патологической физиологии, Запорожский государственный медицинский университет, Украина. Ганчева О. В., д-р мед. наук, профессор, зав. каф. патологической физиологии, Запорожский государственный медицинский университет, Украина.

\section{References}

[1] Grassi, G., Mark, A., \& Esler, M. (2015). The Sympathetic Nervous System Alterations in Human Hypertension. Circulation Research, 116(6), 976-990. https://doi.org/10.1161/circresaha.116.303604

[2] Jamali, H. K., Waqar, F., \& Gerson, M. C. (2017). Cardiac autonomic innervation. Journal of Nuclear Cardiology, 24(5), 1558-1570. https:// doi.org/10.1007/s12350-016-0725-7
[3] Wang, Y. T., \& Golledge, J. (2013). Neuronal Nitric Oxide Synthase and Sympathetic Nerve Activity in Neurovascular and Metabolic Systems. Current Neurovascular Research, 10(1), 81-89. https://doi. org/10.2174/156720213804805963

[4] Olivenza, R., Moro, M. A., Lizasoain, I., Lorenzo, P., Fernandez, A. P., Rodrigo, J., Bosca, L., \& Leza, J. C. (2000). Chronic stress induces the expression of inducible nitric oxide synthase in rat brain cortex. Journal of Neurochemistry, 74(2), 785-791. https://doi.org/10.1046/ j.1471-4159.2000.740785.x

[5] Forstermann, U., \& Sessa, W. C. (2012). Nitric oxide synthases: regulation and function. European Heart Journal, 33(7), 829-837. https://doi.org/10.1093/eurheartj/ehr304

[6] Krowicki, Z. K., Sharkey, K. A., Serron, S. C., Nathan, N. A., \& Hornby, P. J. (1997). Distribution of nitric oxide synthase in rat dorsal vagal complex and effects of microinjection of nitric oxide compounds upon gastric motor function. Journal of Comparative Neurology, 377(1), 4969. https://doi.org/10.1002/(sici)1096-9861(19970106)377:1<49::aidcne6>3.0.co;2-j

[7] Dornas, W. C., \& Silva, M. E. (2011). Animal models for the study of arterial hypertension. Journal of Biosciences, 36(4), 731-737. https:// doi.org/10.1007/s12038-011-9097-y

[8] Kolesnyk, Y. M., Hancheva, O. V., Abramov, A. V., Ivanenko, T. V., Tyschenko, S. V., Kuzio, N. V. (2015). Sposib modeliuvannia symptomatychnoi arterialnoi hipertenzii u dribnykh hryzuniv [Method for modeling symptomatic hypertension in rodents]. Ukraine Patent UA 102234. [in Ukrainian]. Retrieved from https://base.uipv.org/searchINV/search.php?action=viewdetails\&IdClaim=217097

[9] Kolesnyk, Y. M., Hancheva, O. V., Abramov, A. V., Kolesnyk, M. Y., Ivanenko, T. V., Tishchenko, S. V., Danukalo, M. V., \& Fedotova, M. I. (2017). Sovremennye podkhody i novye metodicheskie vozmozhnosti v ocenke funkcional'nogo sostoyaniya melkikh laboratornykh zhivotnykh [Modern approaches and new methodological possibilities in the functional state of small laboratory animals assessing]. Pathologia, 14(3), 364-370. [in Russian] https://doi.org/10.14739/23101237.2017.3.118770

[10] Paxinos, G. \& Watson, C. (1986). The Rat Brain in Stereotaxic Coordinates. Academic Press, New York.

[11] Kumar, G., \& Rudbeck, L. (2009). Immunohistochemical staining methods. Educational Guide. 5th ed. Carpinteria, California: Dako North America.

[12] Ferreira, T. \& Rasband, W. (2012). ImageJ User Guide-IJ1.46r. Retrieved from http://imagej.nih.gov/ij/docs/guide

[13] Zaitsev, V. M., Liflyandskii, V. G., \& Marinkin, V. I. (2003). Prikladnaya meditsinskaya statistika [Applied medical statistics]. Sankt-Peterburg: Foliant. [in Russian].

[14] Calabrese, V., Mancuso, C., Calvani, M., Rizzarelli, E., Butterfield, D. A., \& Stella, A. M. G. (2007). Nitric oxide in the central nervous system: neuroprotection versus neurotoxicity. Nature Reviews Neuroscience, 8(10), 766-775. https://doi.org/10.1038/nrn2214

[15] Herring, N., Zaman, J. A. B., \& Paterson, D. J. (2001). Natriuretic peptides like NO facilitate cardiac vagal neurotransmission and bradycardia via a cGMP pathway. American Journal of Physiology-Heart and Circulatory Physiology, 281(6), H2318- $\mathrm{H} 2327$.

[16] Ogawa, H., Mizusawa, A., Kikuchi, Y., Hida, W., Miki, H., \& Shirato, K. (1995). Nitric-oxide as a retrograde messenger in the nucleus-tractus-solitarii of rats during hypoxia. Journal of Physiology-London, 486(2), 495-504. https://doi.org/10.1113/jphysiol.1995.sp020828

[17] Sy, G. Y., Bruban, V., Bousquet, P., \& Feldman, J. (2001). Nitric oxide and central antihypertensive drugs - One more difference between catecholamines and imidazolines. Hypertension, 37(2), 246-249. https://doi.org/10.1161/01.hyp.37.2.246

[18] Mollnau, H., Wendt, M., Szocs, K., Lassegue, B., Schulz, E., Oelze, M., Li, H. G., Bodenschatz, M., August, M., Kleschyov, A. L., Tsilimingas, N., Walter, U., Forstermann, U., Meinertz, T., Griendling, K., \& Munzel, T. (2002). Effects of angiotensin II infusion on the expression and function of $\mathrm{NAD}(\mathrm{P}) \mathrm{H}$ oxidase and components of nitric Oxide/ cGMP signaling. Circulation Research, 90(4), E58-E65. https://doi. org/10.1161/01.res.0000012569.55432.02

[19] Moreira, J. D., Pernomian, L., Gomes, M. S., Moreira, R. P., do Prado, A. F., da Silva, C., \& de Oliveira, A. M. (2016). Enhanced nitric oxide generation from nitric oxide synthases as the cause of increased peroxynitrite formation during acute restraint stress: Effects on carotid responsiveness to angiotensinergic stimuli in type-1 diabetic rats. European Journal of Pharmacology, 783, 11-22. https://doi.org/10.1016/j. ejphar.2016.04.050 